\section{Comparison of handling, pressure and wearing comfort of different compression devices for decongestion therapy}

Kerstin Protz, ${ }^{1}$ Stefanie Reich-Schupke, ${ }^{2}$ Matthias Augustin, ${ }^{1}$

Kristina Hagenström ${ }^{1}$

${ }^{1}$ University Medical Center Hamburg

Eppendorf (UKE), Institute for Health

Services Research in Dermatology and

Nursing (IVDP), CWC - Comprehensive

Wound Center, Hamburg; ${ }^{2}$ Department

of Dermatology, Venerology and

Allergology, Ruhr-University Bochum,

Bochum, Germany

\section{Introduction}

Compression therapy is an effective therapeutic measure for prevention and therapy of venous leg ulcers (VLU) as well as their recurrence. If properly performed, it causes an increase in venous return, reduces pressure and volume overload in the vein system of the leg. Also it reduces edema, improves pathological changes in micro and macro circulation, and reduces pain. ${ }^{1,2}$ In the decongestion phase a florid VLU needs to be treated with strong compression. ${ }^{3,4}$ For this purpose, short-stretch bandages, multicomponent systems or adaptive compression bandages can be used. The success of compression bandaging depends on the experience, knowledge and practical skills of the supplier. ${ }^{5,6}$ Studies indicate that knowledge and skills of users are insufficient. ${ }^{7-9}$ Badly performed compression bandagings are often rejected by patients. ${ }^{10,11}$ The quality of application has a huge influence on the success of therapy.

\section{Materials and Methods}

This study investigates the quality of application and the required time to create a phlebological compression bandaging with various materials: short-stretch bandages including padding, eight different multicomponent systems and one adaptive compression bandage. Additinally, user-friendliness was determined, the pressure of the compression bandaging was measured, and the wearing comfort was assessed. This provided valid data for the estimation of efficiency, user-friendliness and security of application of the examined materials. Also it enabled the comparison of the examined options of treatment with each other.

The mentioned study was published in 2017 with the title Compression devices for decongestion therapy: A cross-sectional observational survey of handling, pressure, and comfort in Hautarzt. ${ }^{12}$

\section{Results}

A total of 302 compression bandagings were performed by 137 participants. More than $80 \%$ of these were nurses, about $10 \%$ were medical assistants, and others were physicians, podiatrists and physiotherapists. During this survey, 134 bandagings with short-stretch bandages including padding, 128 bandagings with multi-component systems and 40 bandagings with an adaptive compression bandage were performed.

\section{Pressure}

The pressure of a phlebological compression bandaging with short-stretch bandages and padding decreases already a few minutes after completion of the bandaging. ${ }^{13}$ Therefore, the participants were asked to applicate these bandagings with an initial pressure value of 50-60 mmHg. This task was met by 15 participants, while the majority of 82 produced a much lower pressure. Multicomponent systems keep the initial pressure significantly better than short-stretch bandages. ${ }^{14}$ They are designed to provide a pressure value of $40 \mathrm{mmHg}$. 6,13 Some products even have optical markers for assessing the pressure. ${ }^{6}$ Therefore, the participants were asked to achieve a pressure value range between 40 and 50 $\mathrm{mmHg}$ with multicomponent systems. 45 compression bandagings laid within this pressure range and 52 above it. The tested adaptive compression system (Circaid JuxtaCures, medi company) included a pressure measurement template. So the participants were asked to hit a defined pressure value between 35 and $45 \mathrm{mmHg}$. This requirement met 34 of these bandagings.

\section{Time}

The most time of 234 seconds in average, was needed for application of short-stretch bandages with padding. The average time, used for applying the adaptive compression bandages, was 175 seconds. 141 seconds were needed in average to applicate one of the eight multi-component systems.

\section{Difficulty of application}

The participants who had completed a
Correspondence: Kerstin Protz, University Medical Center Hamburg Eppendorf (UKE), Institute for Health Services Research in Dermatology and Nursing (IVDP), CWC Comprehensive Wound Center, Martinistr. 52, Bethanien - Höfe Eppendorf, 20246 Hamburg, Germany.

Tel.: +39.49.(0).1511.513 7749

Fax: +39.49.(0).4074.1040160.

E-mail: kerstin.protz@gmx.de

Conference presentation: International Compression Club (ICC) Meeting, Rotterdam, 2018.

This work is licensed under a Creative Commons Attribution 4.0 License (by-nc 4.0).

CCopyright K. Protz et al., 2018

Licensee PAGEPress, Italy

Veins and Lymphatics 2018; 7989

doi:10.4081/vl.2018.7989

compression treatment judged the difficulty of the applying on a questionnaire with six answer options: very simple, simple, neither simple nor difficult, difficult and very difficult. Of the participants who applied bandagings with short-stretch bandages and padding, $38.8 \%$ found it difficult and $25.4 \%$ easy. Performing compression bandagings with multi-component systems was rated by $53.1 \%$ as easy. The application of an adaptive compression bandage was rated by $50 \%$ as neither easy nor difficult.

\section{Comfort}

95 of the participants who wore bandagings with short-stretch bandages with padding were not able to get into their own shoes anymore. 6 got in their shoes by moving the bandages. This proportion was with 80 participants similar for the multicomponent systems. The best result was shown by the adaptive compression bandage, which only consists of a simple compression stocking in the foot area. All participants who had put it on were able to get into their shoes. The bandagings with short-stretch bandages with padding were rated by $37.7 \%$ as pleasant. For multicomponent systems $65 \%$ expressed this view and the adaptive compression bandages were rated by $94.6 \%$ as pleasant.

\section{Conclusions}

Pressure and comfort of compression treatment influence the efficiency of therapy. The required time for the application and the complexity of the performance are essential for the economic aspects of care. This study considers all four 
aspects and compares in this framework the three most common care options used in the initial decongestion phase for people with VLU. Under all aspects today's most commonly used option, short-stretch bandages with padding, showed the worst results.

\section{References}

1. Dissemond J, Protz K, Reich-Schupke $\mathrm{S}$, et al. Kompressionstherapie des Ulcus cruris. Hautarzt 2016;67:311-25.

2. Partsch H, Mortimer P. Compression for leg wounds. Br J Dermatol 2015;173: 359-69.

3. Amsler F, Willenberg T, Blättler W. In search of optimal compression therapy for venous leg ulcers: A meta-analysis of studies comparing divers bandages with specifically designed stockings. J Vasc Surg 2009;50:668-74.

4. Mosti G. Kompressionstherapie bei Veneninsuffizienz und arteriellen Erkrankungen. 2014;43:127-33.

5. Protz K, Dissemond J, Lulay G, et al.
Praxisprobleme und Therapiehürden Kompressionstherapie bei Ulcus cruris venosum.

Pflegezeitschrift 2016;69:335-40.

6. Weindorf M, Stoffels I, Klode J, Dissemond J. Einfluss visueller Kontrollsysteme auf den Druck von Kompressionsverbänden - Erste Resultate einer prospektiven klinischen Untersuchung verschiedener Anwenderkollektive. Phlebologie 2012;41:18-24.

7. Coull A, Tolson D, McIntosh J. Class$3 \mathrm{c}$ compression bandaging for venous ulcers: comparison of spiral and figureof-eight techniques. J Adv Nurs 2006;54:274-83.

8. Protz K, Heyer K, Dörler $M$ et al. Kompressionstherapie - Kenntnisse und Anwendungspraxis. J Dtsch Dermatol Ges 2014;12:794-802.

9. Stansal A, Lazareth I, Michon Pasturel $\mathrm{U}$, et al. Compression therapy in 100 consecutive patients with venous leg ulcers. J Mal Vasc 2013;38:252-8.

10. Renner R, Gebhardt C, Simon JC. Compliance hinsichtlich der Kompressionstherapie bei Patienten mit floridem Ulcus cruris venosum. Ergebnisse einer Querschnittsuntersuchung. Med Klin 2010;105:1-6.

11. Williams AF. Working in partnership with patients to promote concordance with compression bandaging. $\mathrm{Br} \mathrm{J}$ Community Nurs 2012;17:S1-16.

12. Protz K, Reich-Schupke S, Klose K, et al. Kompressionsmittel für die Entstauungstherapie. Vergleichende Erhebung im Querschnitt zu Handhabung, Anpressdruck und Tragegefühl. Hautarzt (2017); Der Hautarzt, 69(3), 232-241.

13. Jünger M, Ludwig A, Bahboht $S$, Haase H. Comparison of interface pressures of three compression bandaging systems used on healthy volunteers. J Wound Care 2009;18:476-80.

14. Protz K, Heyer K, Verheyen-Cronau I, Augustin M. Loss of interface pressure in various compression bandage systems over seven days. Dermatology 2014;229:343-52. 